\title{
OPEM
}

www.opem.org

Oriental Pharmacy and Experimental Medicine 2008 7(5), 549-555

DOI 10.3742/OPEM.2008.7.5.549

\section{Modulation of the aqueous extract of Bupleuri radix on glycine-induced current in the acutely dissociated rat periaqueductal gray neurons}

\author{
Yun-Hee Sung ${ }^{1}$, Mal-Soon Shin ${ }^{1}$, Tae-Soo Kim ${ }^{1}$, Sang-Won Lee ${ }^{2}$, Youn-Jung Kim ${ }^{2}$, Hye-Sook Shin ${ }^{2}$, \\ Hong $\mathrm{Kim}^{3}$ and Chang-Ju Kim ${ }^{1, *}$
}

${ }^{1}$ Kohwang Medical Research Institute, Department of Physiology, College of Medicine, Kyung Hee University; ${ }^{2}$ Department of Nursing Science, College of Nursing, Kyung Hee University, 1 Hoigi-dong, Dongdaemoon-gu, Seoul 130701, Republic of Korea: ${ }^{3}$ Department of Oriental Sports Medicine, College of Herbal Bio-industry, Daegu Haany University, Gyeongsan-si 712-715, Republic of Korea

\begin{abstract}
SUMMARY
Bupleuri radix (Umbelliferae), the dried root of Bupleurum Chinense DC, has been clinically used to mitigate pain sensation. The descending pain control system consists of three major components, and modulation of pain in the periaqueductal gray is the most extensively studied descending pain control system. However, the relation of Bupleuri radix on the descending pain control system has not been clarified. In the present study, modulation of the aqueous extract of Bupleuri radix on glycine-induced ion current in the acutely dissociated periaqueductal gray neurons was investigated by using nystatin-perforated patch-clamp technique under voltage-clamp condition. In the present results, the glycine-induced ion current was significantly suppressed by $0.1 \mathrm{mg} / \mathrm{ml}$ Bupleuri radix, while treatment with $10^{-5} \mathrm{M}$ naltrexone, opioid receptor antagonist, alleviated Bupleuri radix-induced inhibition on glycine-induced ion current. The present study showed that the aqueous extract of Bupleuri radix may activate descending pain control system through inhibition on glycine-induced ion current in the periaqueductal gray neurons and this effect is mediated by opioid receptors.
\end{abstract}

Key words: Bupleuri radix; Glycine; Periaqueductal gray; Naltrexone; Patch Clamp

\section{INTRODUCTION}

Pain is defined as unpleasant perception of a nociceptive sensation (Verri et al., 2006). Nociception or nociceptive sensation is resulted from the various neuronal circuits within central nervous system (CNS). The descending pain control system consists of three major components: the periaqueductal gray (PAG) of the midbrain, the

*Correspondence: Chang-Ju Kim, Department of Physiology, College of Medicine, Kyung Hee University, 1 Hoigidong, Dongdaemoon-gu, Seoul 130-701, Republic of Korea. Tel: +8229610407; Fax: +8229642195; E-mail: changju@khu.ac.kr rostroventral medulla including the nucleus raphe magnus, and the spinal dorsal horn. Of these, modulation of pain in the PAG is the most extensively studied pain control system (Fields et al., 1991). It was reported that electrical stimulation on the PAG produces antinociception and depresses the response of multi-receptive spinal neurons to noxious peripheral stimuli in rats (Millan et al., 1987). Microinjection of dipyrone into the PAG inhibited spinal neuronal responses to peripheral noxious stimulation (Vasquez and Vanegas, 2000) and suppressed tail flick reflex (Tortorici and Vanegas, 1994).

Several neurotransmitters in the PAG participate 
in the control of nociception. Among them, endogenous opioids, glycine, and glutamate seem to play a crucial role in the processing of pain regulatory signals within this area (O'Sullivan et al., 1992; Min et al., 1996; Maione et al., 2000). Glycine is a simplest amino acid and has diverse metabolic functions within mammalian CNS, and serves as a neurotransmitter at inhibitory synapses (Betz and Laube, 2006). Glycinergic transmission is associated with the processing of motor and sensory information that controls movement, vision, audition, and inflammatory pain sensitization (Lopez-Corcuera et al., 2001; Harvey et al., 2004). Related to the pain regulation, glycine is known to induce pain by activating the inhibitory interneurons in the PAG (Gurwitz, 2001). Opioid peptides, on the other hand, are known to produce analgesic effects by blocking the inhibitory interneurons and activating the PAG antinociceptive pathway (Basbaum and Fields, 1984). It has been reported that these effects of opiates and opioid peptides are elicited through activating potassium channels (Madison and Nicoll, 1988; Han et al., 1999) or inhibiting calcium channels (Rhim and Miller, 1994; Kim et al., 1997).

Bupleuri radix (Umbelliferae), the dried root of Bupleurum Chinense DC, is one of the most important crude drugs used in traditional medicine (Li et al., 2005). Bupleuri radix has various pharmaceutical effects such as anti-cancer (Motoo and Sawabu, 1994), anti-viral (Ushio and Abe, 1991), and antiinflammatory effects (Bermejo Benito et al., 1998). Clinically, this herb has been used to treat for inflammation, hepatic injury, fever, immunity, and to mitigate pain sensation (Zhou et al., 2006). However, the effect of the aqueous extract of Bupleuri radix on the descending pain control system has not been clarified.

In the present study, we investigated the modulation of the aqueous extract of Bupleuri radix on glycine-induced ion current in the acutely dissociated PAG neurons by using the nystatinperforated patch-clamp technique under voltage- clamp conditions.

\section{MATERIALS AND METHODS}

\section{Preparation of PAG neurons}

The PAG neurons were freshly dissociated using technique as previously described elsewhere (Kim et al., 1997; Han et al., 1999). In brief, 10- to 15-dayold Sprague-Dawley rats of both sexes were decapitated under Zoletil $50^{\circledR}$ anesthesia $(50 \mathrm{mg} /$ kg; i.m.; Vibac Laboratories, France). The brain was removed and the transverse slices ( $400 \mu \mathrm{m}$ thickness) were made with a microslicer (DTK-1000, DSK, Japan). Slices were pre-incubated with $5 \% \mathrm{CO}_{2}$ at room temperature for $30 \mathrm{~min}$. Then, the slices were treated with pronase (protease XIV, $1 \mathrm{mg} / 6 \mathrm{ml}$ of the oxygenated incubation solution) for $40-80 \mathrm{~min}$ at $32^{\circ} \mathrm{C}$ and subsequently with thermolysin (protease $\mathrm{X}, 1 \mathrm{mg} / 6 \mathrm{ml}$ ) for $10-20 \mathrm{~min}$ at $32^{\circ} \mathrm{C}$. After enzyme treatment, the slices were kept in the enzyme-free incubation solution for $1 \mathrm{~h}$. PAG region was identified in a $60 \mathrm{~mm}$ culture dish coated with silicone under a binocular microscope (SZ-ST, Olympus, Japan), and was micropunched out from the slice with an electrolytically polished injection needle. The micropunched PAG regions were mechanically dissociated in a different dish with fire-polished fine glass Pasteur pipettes in $35 \mathrm{~mm}$ plastic culture dishes (3801, Falcon, USA) filled with standard solution. The dissociation procedure was done under an inverted phasecontrast microscope (CK-2, Olympus, Japan). The dissociated neurons usually adhered to the bottom of the dish within $20 \mathrm{~min}$. These cells were remained viable for electrophysiological studies up to $6 \mathrm{~h}$ after dissociation.

\section{Solutions}

The ionic composition of the incubation solutions was (in mmol/l): $\mathrm{NaCl} 124, \mathrm{KCl} 5, \mathrm{KH}_{2} \mathrm{PO}_{4}$ 1.2, $\mathrm{MgSO}_{4} 1.3, \mathrm{CaCl}_{2}$ 2.4, glucose 10, and $\mathrm{NaHCO}_{3} 24$. The $\mathrm{pH}$ was adjusted to 7.4 by continuous bubbling with $95 \% \mathrm{O}_{2}$ and $5 \% \mathrm{CO}_{2}$. The composition of the 
standard external solution was (in mmol/l): $\mathrm{NaCl}$ $150, \mathrm{KCl} 5, \mathrm{MgCl}_{2} 1, \mathrm{CaCl}_{2} 2$, glucose 10 , and N-2hydroxyethylpiperazine- $N$ '-2-ethanesulphonic acid (HEPES) 10. The $\mathrm{pH}$ was adjusted to the 7.4 with tris-hydroxymethylaminomethane (Tris-Base). The composition of the internal pipette solution for nystatin-perforated recording contained (in $\mathrm{mM}$ ): $\mathrm{KCl} 150$ and HEPES 10 . The $\mathrm{pH}$ was adjusted to 7.2 by adding Tris-base. A stock solution containing 10 $\mathrm{mg} / \mathrm{ml}$ nystatin was prepared and added in a final concentration of $200 \mu \mathrm{g} / \mathrm{ml}$ to the patch pipette solution.

\section{Drugs}

Bupleuri radix (Umbelliferae) used in this experiment was obtained from Kyung-Dong Market (Seoul, Republic of Korea). In order to obtain the aqueous extract of Bupleuri radix, it was subsequently heatextracted, pressure-filtered, and concentrated with a rotary evaporator. The resulting $17.92 \mathrm{~g}$ of powder (yield of $35.84 \%$ ) was obtained from $50 \mathrm{~g}$ of Bupleuri radix through lyophilization for $24 \mathrm{~h}$ by a drying machine (Ilsin, Seoul, Republic of Korea).

Most drugs used in this experiment were obtained from Sigma Chemical Co. (St. Louis, USA). Drugs were added to the standard solution at the final concentrations provided in the text and were applied using a rapid application system termed the "Y-tube method" as described elsewhere (Han et al., 1999; Kim et al, 2001). By this technique, the standard solution surrounding a neuron could be exchanged within 10 - 20 ms.

\section{Electrical measurement}

Electrical recording was performed in the nystatinperforated patch recording mode under voltageclamp condition. Patch pipette was prepared from glass capillaries with an outer diameter of $1.5 \mathrm{~mm}$ on a 2-stage puller (PB-7, Narishige, Japan). The resistance between the recording electrode filled with the internal pipette solution and the reference electrode was 6-8 M $\Omega$. After stable perforated patch formation, the series resistance ranged from
16 to $25 \mathrm{M} \Omega$. Electrical stimulation, currents recording, and filtration of currents (at $2.9 \mathrm{kHz}$ ) were obtained with an EPC-7 patch-clamp amplifier (List-Electronic, Germany). The currents and voltage were monitored on a pen recorder. All experiments were conducted at room temperature $\left(22-24^{\circ} \mathrm{C}\right)$.

\section{Statistical analysis}

The results are presented as the mean standard error of the mean (S.E.M.). The data were analyzed by one-way ANOVA followed by Duncan's post-hoc test. The differences were considered statistically significant at $P<0.05$.

\section{RESULTS}

\section{Ion currents activated by various concentrations of} the aqueous extract of Bupleuri radix

In the nystatin-perforated patch-clamp mode, experiments were carried out at a holding potential $\left(V_{\mathrm{H}}\right)$ of $-50 \mathrm{mV}$. The aqueous extract of Bupleuri radix was applied every $2 \mathrm{~min}$ and ion current induced by $0.5 \mathrm{mg} / \mathrm{ml}$ Bupleuri radix was used as the control value. Inward currents induced by Bupleuri radix at various concentrations were recorded. The magnitude of ion currents elicited by Bupleuri radix at concentrations of $0.01 \mathrm{mg} / \mathrm{ml}, 0.05$ $\mathrm{mg} / \mathrm{ml}, 0.1 \mathrm{mg} / \mathrm{ml}, 1 \mathrm{mg} / \mathrm{ml}$, and $3 \mathrm{mg} / \mathrm{ml}$ were $0.04 \pm 0.01,0.08 \pm 0.04,0.22 \pm 0.01,1.53 \pm 0.12$, and $5.31 \pm 1.61$ of the control value set as 1 , respectively. In the present results, the aqueous extract of Bupleuri radix elicited ion currents in the PAG neurons as concentration-dependent manner (Fig. 1).

\section{Modulation of the aqueous extract of Bupleuri radix on glycine-induced ion current}

To determine the modulation of Bupleuri radix on glycine-induced ion current, magnitude of ion current elicited by $10^{-5} \mathrm{M}$ glycine was used as the control value. The concentrations of $0.01 \mathrm{mg} / \mathrm{ml}$, $0.05 \mathrm{mg} / \mathrm{ml}, 0.1 \mathrm{mg} / \mathrm{ml}$, and $0.5 \mathrm{mg} / \mathrm{ml}$ Bupleuri radix were applied simultaneously with $10^{-5} \mathrm{M}$ glycine. Bupleuri radix at concentrations of 0.01 
A

$$
V_{H}=-50 \mathrm{mV}
$$
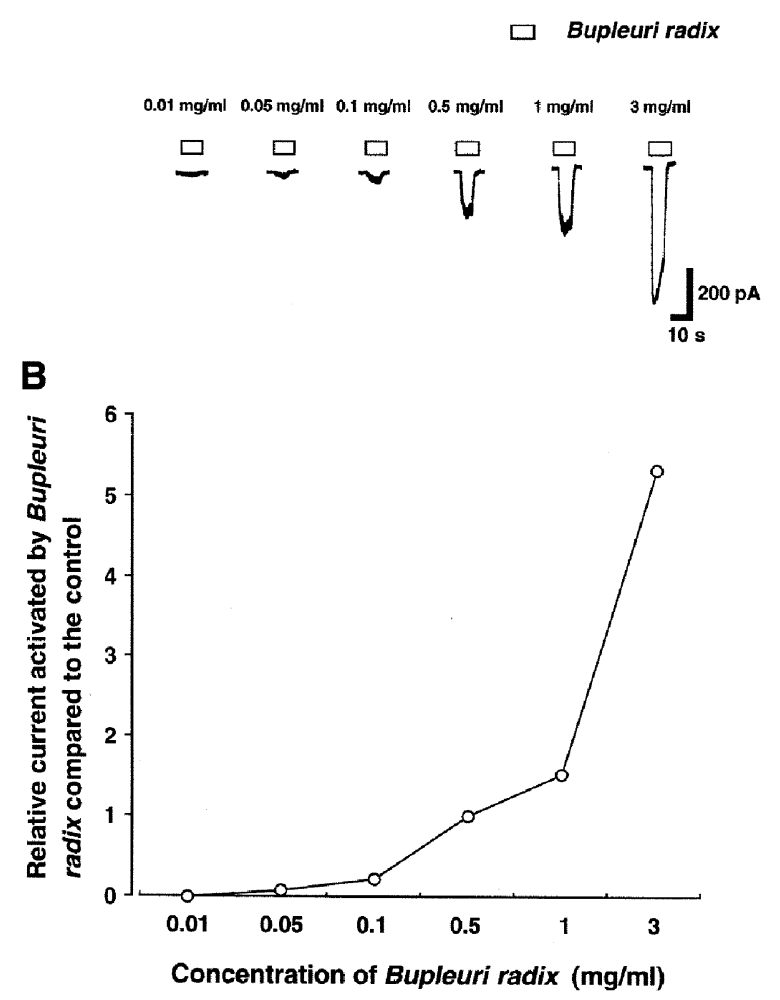

Fig. 1. Ion currents induced by Bupleuri radix. Application of the aqueous extract of Bupleuri radix elicited ion currents in periaqueductal gray neurons as concentration-dependent manner.

$\mathrm{mg} / \mathrm{ml}, 0.05 \mathrm{mg} / \mathrm{ml}, 0.1 \mathrm{mg} / \mathrm{ml}$, and $0.5 \mathrm{mg} / \mathrm{ml}$ inhibited glycine-induced ion current as $0.93 \pm 0.01$, $0.86 \pm 0.02,0.73 \pm 0.02$, and $0.86 \pm 0.01$ of the control value set as 1 , respectively. In the present results, the glycine-induced ion current was significantly suppressed by the aqueous extract of Bupleuri radix at the concentrations of $0.05 \mathrm{mg} / \mathrm{ml}, 0.1 \mathrm{mg} / \mathrm{ml}$, and $0.5 \mathrm{mg} / \mathrm{ml}$ (Fig. 2).

Effect of naltrexone on Bupleuri radix-induced inhibition on glycine-induced ion current

To evaluate the involvement of opioid receptor in the Bupleuri radix-induced inhibition on glycineinduced ion current in the PAG neurons, naltrexone that is non-selective opioid receptor antagonist,
A
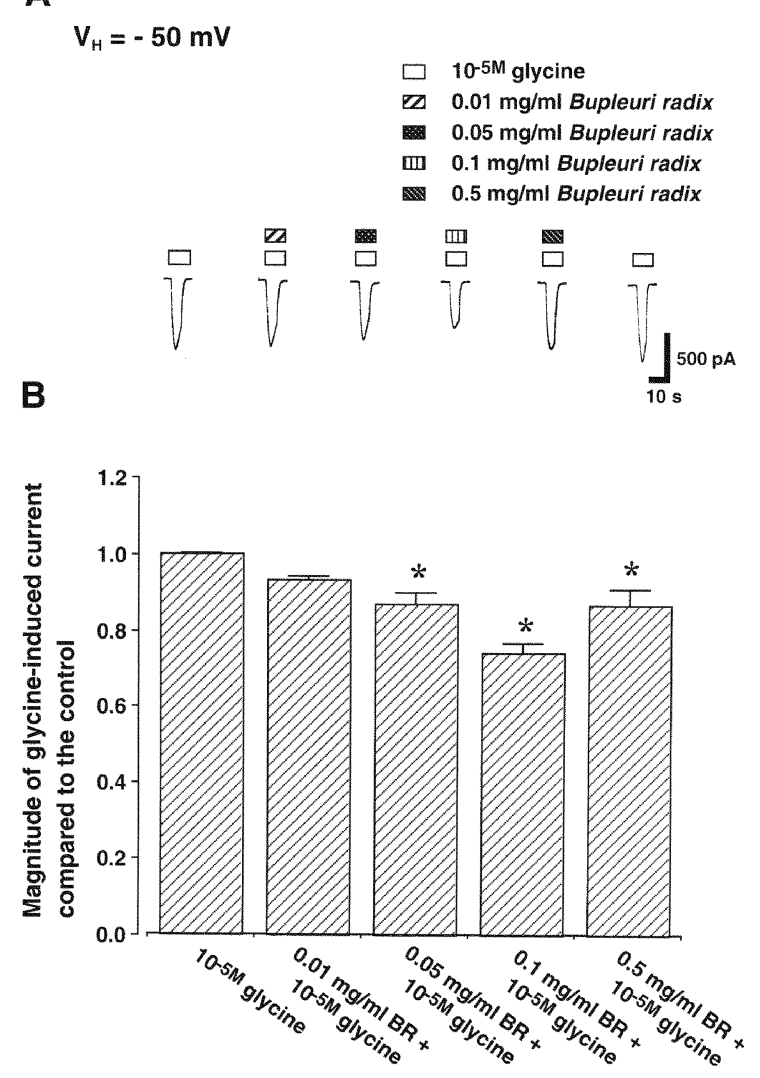

Fig. 2. Modulation of the aqueous extract of Bupleuri radix on glycine-induced ion current. The glycineinduced ion current was significantly inhibited by $0.05 \mathrm{mg} / \mathrm{ml}, 0.1 \mathrm{mg} / \mathrm{ml}$, and $0.5 \mathrm{mg} / \mathrm{ml}$ of Bupleuri radix. $10^{-5} \mathrm{M}$ glycine was used as a control value. ${ }^{*} P<$ 0.05 compared to the control. BR: Bupleuri radix.

was applied simultaneously with the aqueous extract of Bupleuri radix. In the present results, ion current induced by $10^{-5} \mathrm{M}$ glycine was decreased to $0.73 \pm$ 0.02 by $0.1 \mathrm{mg} / \mathrm{ml}$ of Bupleuri radix, while treatment with $10^{-5} \mathrm{M}$ naltrexone alleviated glycine-induced ion current to $0.94 \pm 0.01$, with the control value set as 1 (Fig. 3). These results showed that naltrexone alleviated the aqueous extract of Bupleuri radixinduced inhibition on glycine-activated ion current.

\section{DISCUSSION}

In the present study, the aqueous extract of Bupleuri radix at high concentrations (above 0.1 
A
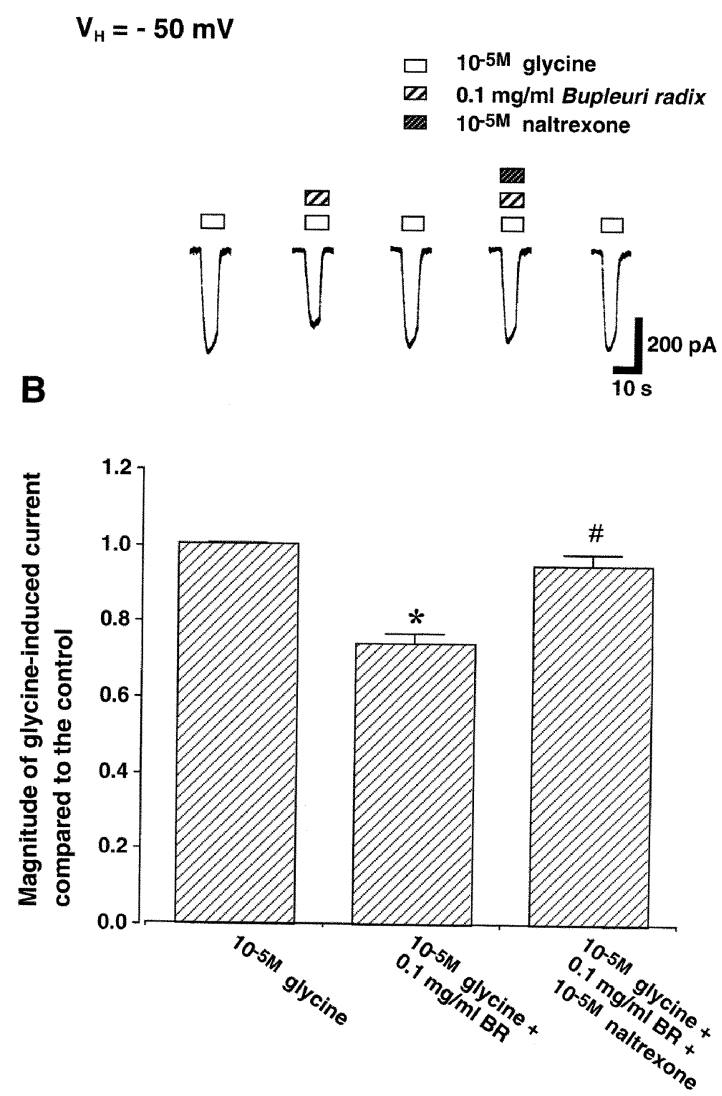

Fig. 3. Effect of naltrexone on Bupleuri radix-induced inhibition on glycine-induced ion current. Inhibitory action of Bupleuri radix on glycine-induced ion current was abolished by naltrexone application. $10^{-5} \mathrm{M}$ glycine was used as a control value. ${ }^{*} P<0.05$ compared to the control. BR: Bupleuri radix.

$\mathrm{mg} / \mathrm{ml}$ ) elicited ion current in a concentrationdependent manner in the PAG neurons. Bupleuri radix, however, did not induced ion current by itself at concentrations below $0.01 \mathrm{mg} / \mathrm{ml}$. For the next experiments, we used Bupleuri radix at concentrations of $0.05 \mathrm{mg} / \mathrm{ml}, 0.1 \mathrm{mg} / \mathrm{ml}$, and $0.5 \mathrm{mg} / \mathrm{ml}$ in order to investigate the effect of Bupleuri radix at low concentrations on the glycineinduced ion current in acutely dissociated rat PAG neurons.

The major finding of this study is that the glycine-induced ion current in PAG neurons was suppressed by the aqueous extract of Bupleuri radix at concentrations of $0.05 \mathrm{mg} / \mathrm{ml}, 0.1 \mathrm{mg} / \mathrm{ml}$, and $0.5 \mathrm{mg} / \mathrm{ml}$ and the most potent inhibitive effect on glycine-induced ion current was shown in the 0.1 $\mathrm{mg} / \mathrm{ml}$ of Bupleuri radix in this study. Previous studies revealed that glycine plays an important role in the modulation of analgesic action at the level of PAG (Sato et al., 1991; Todd et al., 1996; Fujiwara et al., 1998). Maione et al. (2000) showed that glycine acts as an inhibitory nociceptive transmitter in PAG. In addition, Gurwitz (2001) reported that inhibition of glycine transporter in the brain and spinal cord may relieve pain. Recently, it was suggested that the analgesic effects of Oriental medicinal herbs such as Corydalis tuber and Chelidonii herba are closely related to the inhibition on glycine in the PAG neurons (Shin et al., 2003; Cheong et al., 2004). The present results showed the possibility that Bupleuri radix may have an analgesic effect by activating the descending pain control system through the inhibition on glycine-induced ion current in PAG neurons.

It is well documented that analgesic action of PAG is mediated by opioid system (Shin et al., 2003; Cheong et al., 2004). Pert and Walter (1976) reported that administration of naloxone, nonselective opioid receptor antagonist, to rats reduced analgesic effect induced by electrical stimulation on the PAG. Wei et al. (2003) also showed that central analgesia was blocked by non-selective opioid receptor antagonists such as naloxone, naltrexone, and nalmephene. Recent study demonstrated that microinjection of naltrexone into the ventrolateral PAG significantly attenuated the tolerance to systemic morphine during the pain test such as hot plate and formalin test (Lane et al., 2005). In the present results, Bupleuri radix-induced inhibition on the glycine-induced ion current was abolished by naltrexone application. Theses results show that opioid receptors are closely involved in the inhibitory action of Bupleuri radix on glycineinduced ion current in the PAG neurons, suggesting that some components of Bupleuri radix exert analgesic action through opioid receptors in the 
PAG neurons. However, the inhibitory action of Bupleuri radix on glycine-induced ion current was not eliminated completely by naltrexone application, suggesting that other components of Bupleuri radix may induce analgesic action through direct modulation on glycine-receptors in the PAG neurons.

Bupleuri radix contains a lot of organic compound, and saikosaponins has been suggested as the main pharmaceutical component of this herb (Li et al., 2005). Ushio and Abe (1991) showed that saikosaponin increases phagocytosis activity of macrophage. Bermejo Benito et al. (1998) reported that saikosaponin exerts anti-inflammatory effect on phorbol myristate acetate- induced ear edema in mice. It can be suspected that saikosaponin is the main component of Bupleuri radix responsible for its inhibitory effect on the glycine-induced ion current.

Here in this study, we have shown that the aqueous extract of Bupleuri radix may activate descending pain control system through inhibition on glycine-induced ion current in the PAG and this effect is mediated by opioid receptors.

\section{ACKNOWLEDGEMENTS}

This research was supported by the MIC (Ministry of Information and Communication), Korea, under the ITRC (Information Technology Research Center) support program supervised by the IITA (Institute of Information Technology Advancement) (IITA2008-(C1090-0801-0002).

\section{REFERENCES}

Basbaum AI, Fields HL. (1984) Endogenous pain control systems: brainstem spinal pathways and endorphin circuitry. Annu. Rev. Neurosci. 7, 309-338.

Bermejo Benito P, Abad Martinez MJ, Silvan Sen AM, Sanz Gomez A, Fernandez Matellano L, Sanchez Contreras S, Diaz Lanza AM. (1998) In vivo and in vitro antiinflammatory activity of saikosaponins. Life Sci. 63, 1147-1156.

Betz H, Laube B. (2006) Glycine receptors: recent insights into their structural organization and functional diversity. J. Neurochem. 97, 1600-1610.

Cheong BS, Choi DY, Cho NH, Lee JD, Chang HK, Shin MC, Shin MS, Kim CJ. (2004) Modulation of Corydalis tuber on glycine-induced ion current in acutely dissociated rat periaqueductal gray neurons. Biol. Pharm. Bull. 27, 1207-1211.

Fields HL, Heinricher MM, Mason P. (1991) Neurotransmitters in nociceptive modulatory circuits. Annu. Rev. Neurosci. 14, 219-245.

Fujiwara K, Kaminishi Y, Inoue Y, Yabuuchi M. (1998) Monoclonal antibody monospecific to glycine for brain immunocytochemistry. Brain Res. 806, 210218.

Gurwitz D. (2001) Profile; glycine transporter GlyT-2 blockers: potential pain-relief and anti-spastic drugs. Drug Discov. Today 6, 1178-1179.

Han SH, Cho YW, Kim CJ, Min BI, Rhee JS, Akaike N. (1999) $\mu$-opioid agonist-induced activation of Gprotein-coupled inwardly rectifying potassium current in rat periaqueductal gray neurons. Neuroscience 90, 209-219.

Harvey R, Depner U, Wssle H, Ahmadi S, Heindl C, Reinold H, Smart T, Harvey K, Schtz B, Akbari O, Zimmer A, Poisbeau P, Welzl H, Wolfer DP, Betz H, Zeilhofer U, Mller U. (2004) GlyR $\alpha 3$ : an essential target for spinal $\mathrm{PGE}_{2}$-mediated inflammatory pain sensitization. Science 304, 884-888.

Kim CJ, Rheee JS, Akaike N. (1997) Modulation of high-voltage activated $\mathrm{Ca}^{2+}$ channels in the rat periaqueductal gray neurons by $\mu$-type opioid agonist. J. Neurophysiol. 77, 1418-1424.

Kim Y, Shin M, Chung J, Kim E, Koo G, Lee C, Kim C. (2001) Modulation of Chelidonii herba on GABA activated chloride currents in rat PAG neurons. Am. J. Chin. Med. 29, 265-279.

Lane DA, Patel PA, Morgan MM. (2005) Evidence for an intrinsic mechanism of antinociceptive tolerance within the ventrolateral periaqueductal gray of rats. Neuroscience 135, 227-234.

Li XQ, Gao QT, Chen XH, Bi KS. (2005) High performance liquid chromatographic assay of saikosaponins from radix Bupleuri in China. Biol. Pharm. Bull. 28, 1736-1742.

Lopez-Corcuera B, Geerlings A, Aragon C. (2001) Glycine neurotransmitter transporters: an update. Mol. Membr. Biol. 18, 13-20. 
Madison D, Nicoll RA. (1988) Enkephalin hyperpolarizes interneurones in the rat hippocampus. J. Physiol. 398, 122-130.

Maione S, Marabese I, Rossi F, Berrino L, Palazzo E, Trabace L. (2000) Effects of persistent nociception on periaqueductal gray glycine release. Neuroscience 97, 311-316.

Millan MJ, Czlonkowski A, Millan MH, Herz A. (1987) Activation of periaqueductal gray pools of âendorphin by analgetic electrical stimulation in freely moving rats. Brain Res. 407, 199-203.

Min BI, Kim CJ, Rhee JS, Akaike N. (1996) Modulation of glycine-induced chloride current in acutely dissociated rat periaqueductal gray neurons by $\mu$ opioid agonist DAGO. Brain Res. 734, 72-78.

Motoo Y, Sawabu N. (1994) Antitumor effects of saikosaponins, baicalin and baicalein on human hepatoma cell lines. Cancer Lett. 86, 91-95.

O'Sullivan MG, Chilton FH, Huggins EM, Jr McCall CE. (1992) Lipopolysaccharide priming of alveolar macrophages for enhanced synthesis of prostanoids involves induction of a novel prostaglandin $\mathrm{H}$ synthase. J. Biol. Chem. 267, 14547-14550.

Pert A, Walter M. (1976) Comparison between naloxone reversal of morphine and electrical stimulation induced antinociception in the rat mesencephalon. Life Sci. 19, 1023-1032.

Rhim H, Miller RJ. (1994) Opioid receptors modulate diverse types of calcium channels in the nucleus tractus solitarius of the rat. J. Neurosci. 14, 7608-7615.

Sato K, Zhang JH, Saika T, Sato M, Tada K, Tohyama M. (1991) Localization of glycine receptor $\alpha_{1}$ subunit mRNA-containing neurons in the rat brain: an analysis using in situ hybridization histochemistry. Neuroscience 43, 381-395.
Shin MC, Jang MH, Chang HK, Lim S, Han SM, Park HJ, Shim I, Lee JS, Kim KA, Kim CJ. (2003) Modulation of Chelidonii herba on glycine-activated and glutamate-activated ion currents in rat periaqueductal gray neurons. Clin. Chim. Acta 337, 93-101.

Todd AJ, Watt C, Spike RC, Sieghart W. (1996) Colocalization of GABA, glycine and their receptors at synapses in the rat spinal cord. J. Neurosci. 16, 974-982.

Tortorici V, Vanegas H. (1994) Putative role of medullary off- and on-cells in the antinociception produced by dipyrone (metamizol) administered systemically or microinjected into PAG. Pain 57, 197-205.

Ushio Y, Abe H. (1991) The effects of saikosaponin on macrophage functions and lymphocyte proliferation. Planta Med. 57, 511-514.

Vasquez E, Vanegas H. (2000) The antinociceptive effect of PAG-microinjected dipyrone in rats is mediated by endogenous opioids of the rostral ventromedical medulla. Brain Res. 854, 249-252.

Verri WA, Jr Cunha TM, Parada CA, Poole S, Cunha FQ, Ferreira SH. (2006) Hypernociceptive role of cytokines and chemokines: Targets for analgesic drug development? Pharmacol. Ther. 112, 116-138.

Wei G, Moss J, Yuan CS. (2003) Opioid-induced immunosuppression: is it centrally mediated or peripherally mediated? Biochem. Pharmacol. 65, 17611766.

Zhou C, Xia G, Zhi D, Chen Y. (2006) Genetic characterization of asymmetric somatic hybrids between Bupleurum scorzonerifolium Willd and Triticum aestivum L.: potential application to the study of the wheat genome. Planta 223, 714-724. 